\title{
A missense mutation in the CD38 gene, a novel factor for insulin secretion: association with Type II diabetes mellitus in Japanese subjects and evidence of abnormal function when expressed in vitro
}

\author{
K. Yagui ${ }^{1}$, F. Shimada ${ }^{1}$, M. Mimura ${ }^{2}$, N. Hashimoto ${ }^{1}$, Y. Suzuki ${ }^{1}$, Y. Tokuyama ${ }^{1}$, K. Nata ${ }^{3}$, A. Tohgo ${ }^{3}$, F. Ikehata ${ }^{3}$, \\ S. Takasawa ${ }^{3}$, H. Okamoto ${ }^{3}$, H. Makino ${ }^{4}$, Y. Saito ${ }^{1}$, A. Kanatsuka ${ }^{1}$ \\ ${ }^{1}$ Department of Internal Medicine II, Chiba University School of Medicine, Chiba, Japan \\ ${ }^{2}$ Department of Internal Medicine, Chiba Rousai Hospital, Ichihara, Japan \\ ${ }^{3}$ Department of Biochemistry, Tohoku University School of Medicine, Sendai, Japan \\ ${ }^{4}$ Department of Laboratory Medicine, Ehime University School of Medicine, Shigenobu, Japan
}

Summary Cyclic adenosine 5'diphosphate-ribose (cADPR) is thought to have a second messenger role in insulin secretion through mobilisation of $\mathrm{Ca}^{2+}$. As human lymphocyte antigen CD38 has both ADP-ribosyl cyclase and cADPR hydrolase activity, it may be important in glucose-induced insulin secretion in islets. Thirty one randomly selected Japanese patients with Type II diabetes mellitus who had firstdegree and/or second-degree relative(s) with Type II diabetes mellitus were screened for mutations of this gene using single-stranded conformation polymorphism. Two variant patterns in exon 3 and exon 4 of the CD38 gene were identified. The variant in exon 3 resulted in an amino acid substitution from $\mathrm{Arg}^{140}$ (CGG) to Trp (TGG). The $\operatorname{Arg}^{140} \operatorname{Trp}$ mutation was observed in 4 of 31 patients, and allele frequencies were significantly different in patients and the control subjects $(p=0.004)$. One patient with this mutation has two missense mutations on beta cell/liver glucose transporter (GLUT2) gene; her mother, who has impaired glucose tolerance, also has this mutation on the CD38 gene and one missense mutation on the GLUT2 gene. Enzyme activity studies using COS-7 cells expressing the $\mathrm{Arg}^{140} \mathrm{Trp}$ mutation showed a reduction in ADP-ribosyl cyclase and cADPR hydrolase activity of around $50 \%$. The $\mathrm{Arg}^{140} \mathrm{Trp}$ mutation on CD38 thus appears to contribute to the development of Type II diabetes mellitus via the impairment of glucose-induced insulin secretion in the presence of other genetic defects. [Diabetologia (1998) 41: 1024-1028]

Keywords CD38 gene, susceptibility, missense mutation, Type II diabetes mellitus, cyclic ADP-ribose, ADP-ribosyl cyclase, cyclic ADP-ribose hydrolase
Genetic factors play an important part in the pathogenesis of Type II diabetes mellitus, a heterogeneous disorder characterised by defects in insulin action as well as insulin secretion [1]. Mutations associated with Type II diabetes have been identified in the insulin [2], insulin receptor [3, 4], glucokinase [5-7] and

Received: 30 December 1997 and in final revised form: 2 April 1998

Corresponding author: Dr. Azuma Kanatsuka, Department of Internal Medicine II, Chiba University School of Medicine, 1-8-1 Inohana, Chuo-ku, Chiba 260-0856, Japan

Abbreviations: cADPR, Cyclic adenosine 5'diphosphate-ribose; PCR, polymerase chain reaction. mitochondrial genes $[8,9]$. However, these mutations seem to be rare in the common form of Type II diabetes, and major genetic causes of this disease remain elusive.

Cyclic adenosine 5'diphosphate-ribose (cADPR) induces the release of $\mathrm{Ca}^{2+}$ from microsomes of pancreatic islets [10] as well as from a variety of other cells [11]. Glucose raises the cADPR concentration in islets [10,12], and cADPR has been shown in vitro to induce insulin secretion from islets rendered permeable by digitonin [10]. Controversial results have been reported in studies using diabetic beta cells such as $o b / o b$ mouse islets and RINm5F cells [13-15]. We recently examined the $\mathrm{Ca}^{2+}$ releasing activity of these diabetic beta cell microsomes and com- 
Table 1. Clinical features of study subjects

\begin{tabular}{lll}
\hline & $\begin{array}{l}\text { Control } \\
\text { subjects }\end{array}$ & $\begin{array}{l}\text { Type II diabetes } \\
\text { patients* }\end{array}$ \\
\hline$n$ & 90 & 31 \\
Age at study (years) & $51 \pm 1$ & $60 \pm 2$ \\
Age at diagnosis (years) & - & $47 \pm 2$ \\
Body mass index (kg/m $\left.{ }^{2}\right)$ & $22.8 \pm 0.3$ & $22.6 \pm 0.5$ \\
HbA $_{1 \mathrm{c}}(\%)$ & $\mathrm{ND}$ & $8.3 \pm 0.4$ \\
Treatment $(\%)$ & & \\
$\quad$ Diet & - & 26 \\
$\quad$ Oral agent & - & 48 \\
$\quad$ Insulin & - & 26
\end{tabular}

* These patients had first-degree and/or second-degree relative(s) with Type II diabetes

pared it with that of the microsomes of normal beta cells such as C57BL/6J mouse islets. We found that the $\mathrm{Ca}^{2+}$ release responses of these diabetic beta cell microsomes were quite different from those of normal islet microsomes [11, 12]. Microsomes from $\mathrm{C} 57 \mathrm{BL} / 6 \mathrm{~J}$ mouse islets, as well as Wistar rat islets, released $\mathrm{Ca}^{2+}$ in response to cADPR, but showed a minimal response to $\mathrm{IP}_{3}$. In contrast to normal islet microsomes, $o b / o b$ mouse islet microsomes were induced to release only a small amount of $\mathrm{Ca}^{2+}$ by cADPR, but much more by $\mathrm{IP}_{3}$. RINm5F cell microsomes released appreciable $\mathrm{Ca}^{2+}$ in response to $\mathrm{IP}_{3}$, but did not respond to cADPR. cADPR may therefore have a second messenger role in insulin secretion by mobilising $\mathrm{Ca}^{2+}$ in normal beta cells, but not in diabetic beta cells.

Human lymphocyte antigen CD38 has been shown to have both ADP-ribosyl cyclase and cADPR hydrolase activities [16] , and is expressed in a variety of tissues and cells, including pancreatic islets [17]. Adenosine triphosphate (ATP), which is generated during glucose metabolism in islets, inhibits the cADPR hydrolase activity of CD38, thereby resulting in an accumulation of cADPR [16]. Moreover, glucose-induced insulin secretion is enhanced in transgenic mice overexpressing the CD38 in pancreatic beta cells [18]. Thus, CD38 is thought to have an important role in glucose-induced insulin secretion in islets. To investigate whether specific CD38 variants are associated with Type II diabetes mellitus, we analysed the CD38 gene in 31 Japanese subjects with Type II diabetes mellitus who had first-degree and/or second-degree relative(s) with Type II diabetes. We examined both ADP-ribosyl cyclase and cADPR hydrolase activities of the mutated CD38 detected in the patients.

\section{Subjects and methods}

Protocol 1. Thirty-one unrelated outpatients with Type II diabetes mellitus who had first-degree and/or second-degree relative(s) with Type II diabetes mellitus were randomly selected at Chiba University Hospital (Table 1). These patients were screened for mutations throughout the whole coding region of CD38. Ninety non-diabetic subjects with no family history of diabetes and normal glucose tolerance after administration of a $75 \mathrm{~g}$ oral glucose tolerance test were used as control subjects. The diagnosis of Type II diabetes mellitus was based on WHO criteria [19]. All patients and control subjects were informed of the purpose of the study, and their consent was obtained. This study was approved by the ethics committee of Chiba University Hospital and was performed in accordance with the Helsinki Declaration of 1975.

Screening for mutations in the CD38 cDNA. DNA was isolated from peripheral white blood cells by the phenol/chloroform method after digestion with proteinase $\mathrm{K}$ [20]. The eight exons and adjacent introns of CD38 [21] were amplified using primers specific for each exon (Table 2). The polymerase chain reaction (PCR) was carried out in a volume of $5 \mu$ l containing $50 \mathrm{ng}$ of genomic DNA, $0.1 \mathrm{U}$ of Taq DNA polymerase (Takara, Otsu, Japan), $10 \mathrm{mmol} / \mathrm{l}$ of Tris- $\mathrm{HCl} \mathrm{pH} \mathrm{8.3,50} \mathrm{mmol/l} \mathrm{of}$ $\mathrm{KCl}, 1.5 \mathrm{mmol} / \mathrm{l}$ of $\mathrm{MgCl}_{2}, 100 \mu \mathrm{mol} / \mathrm{l}$ of dNTP with $10 \mathrm{pmol}$ of ${ }^{32} \mathrm{P}$-labelled specific primers. The PCR conditions were initial denaturation at $94^{\circ} \mathrm{C}$ for $5 \mathrm{~min}$, followed by 30 cycles of denaturation at $94^{\circ} \mathrm{C}$ for $0.5 \mathrm{~min}$, annealing at $50^{\circ} \mathrm{C}$ for $1 \mathrm{~min}$ and extension at $72^{\circ} \mathrm{C}$ for $2.5 \mathrm{~min}$, with a final extension of $10 \mathrm{~min}$. The PCR products were diluted 15 fold with formamide buffer ( $95 \%$ formamide, $0.05 \%$ bromphenol blue, and $0.05 \%$ xylene cyanol), heated at $95^{\circ} \mathrm{C}$ for $3 \mathrm{~min}$, and $1.5 \mu \mathrm{l}$ of each sample were loaded onto a $5 \%$ non-denaturing polyacrylamide gel $\left(30 \times 40 \times 0.03 \mathrm{~cm}\right.$; acrylamide: $\mathrm{N}, \mathrm{N}^{\prime}$-methylene-bisacrylamide $=49: 1)$. Each sample was run on four gels containing $0 \%$ or $5 \%$ glycerol at a room temperature or $4^{\circ} \mathrm{C}$. The gels were then transferred to paper, dried and exposed to film with an intensifying screen for $12 \mathrm{~h}$ at $-70^{\circ} \mathrm{C}$. The sequences of new bands observed by single-stranded conformation polymorphism were determined using phage vector M13.

Protocol 2: Mutagenesis and expression of CD38. CD38 exon 3, carrying the mutation (Arg ${ }^{140} \mathrm{Trp}$ ), and adjacent introns were amplified by PCR from the genomic DNA of the patient. The fragment was subcloned using a kit (pCR-Script Amp SK( + )

Table 2. Sequences of primer pairs for PCR-single-stranded conformation polymorphism analysis of the human CD 38 gene

\begin{tabular}{llll}
\hline Exon & Upstream primer & Downstream primer & Product size (bp) \\
\hline 1 & $5^{\prime}$-CTCCTGCCGGCCTCATCTTC-3' & $5^{\prime}$-GCCCTGCTGTCCCCGCAGTG-3' & 329 \\
2 & $5^{\prime}$-GGCATATAATAGATGCTTCC-3' & $5^{\prime}$-TGGACCTATGAATTGTTACC-3' & 304 \\
3 & $5^{\prime}$-GACATGCTAAATTGATCTCAG-3' & $5^{\prime}$-CAGCAGAAGTCACTCTGTTC-3' & 248 \\
4 & $5^{\prime}$-TCCACTATGACTGAACAGCC-3' & $5^{\prime}$-AGCACTGACTGAGTAACGTC-3' & 244 \\
5 & $5^{\prime}$-CTTAACCAGCTATTGCTAAG-3' & $5^{\prime}$-ACTGTGATATTTGCAACAGG-3' & 223 \\
6 & $5^{\prime}$-TCTGCCTGCTGGTTGTTGAG-3' & $5^{\prime}$-TCCTGAGTCAATTTGTTCCC-3' & 272 \\
7 & $5^{\prime}$-CCTTGTCCAGGGCGTGCTAC-3' & $5^{\prime}$-AAGCTCAGAGGAGGCTAAGG-3' & 258 \\
8 & $5^{\prime}$-AGCGAATTGGACGACAGATG-3' & $5^{\prime}$-CATTGACCTTATTGTGGAGG-3' & 250 \\
\hline
\end{tabular}


Cloning Kit, Stratagene Cloning Systems, LaJolla, Calif., USA), and plasmids carrying the mutant allele were determined by DNA sequencing. An Eco RI-Bgl II fragment with the mutation was substituted for the normal fragment in an expression vector (pSV2-CD38). The identity of the gene was confirmed by DNA sequencing. The pSV2 vector carrying either the wild type or mutant human CD38 cDNA was introduced and expressed in COS-7 cells as described [16, 22, 23].

Western blot analysis. Western blot analysis was carried out using an ECL detection system (Amersham Life Science, Buckinghamshire, UK) as described previously [16, 22, 23]. Blots were probed with the T16 [16, 22-24] (Cosmo Bio Co., Ltd., Tokyo, Japan) monoclonal antibody against human CD38. The band intensity of the expressed CD38 protein was measured using NIH Image software (version 1.57).

Enzyme assays. ADP-ribosyl cyclase and cADPR hydrolase assays were performed as described [16, 22, 23] using COS-7 cell homogenates (10 to $20 \mu \mathrm{g}$ protein) containing equivalent amounts of wild or mutant CD38 protein, as estimated by Western blot analysis. Briefly, a homogenate of COS-7 cells into which either the wild type or mutant CD38 expression vector had been introduced was incubated for 10 to $20 \mathrm{~min}$ at $37^{\circ} \mathrm{C}$ in $0.1 \mathrm{ml}$ of phosphate-buffered saline $(137 \mathrm{mmol} / \mathrm{l}$ $\mathrm{NaCl}, 2.7 \mathrm{mmol} / \mathrm{l} \quad \mathrm{KCl}, 8.1 \mathrm{mmol} / \mathrm{l} \quad \mathrm{Na}_{2} \mathrm{HPO}_{4}, \quad 1.5 \mathrm{mmol} / \mathrm{l}$ $\mathrm{KH}_{2} \mathrm{PO}_{4}, \mathrm{pH} 7.4$ ) with $0.2 \mathrm{mmol} / 1 \mathrm{NAD}^{+}$containing $5 \mu \mathrm{Ci}$ of $\left[{ }^{32} \mathrm{P}\right] \mathrm{NAD}^{+}$(Du Pont NEN, Boston, Massa., USA) for measuring ADP-ribosyl cyclase activity or with $0.2 \mathrm{mmol} / \mathrm{l} \mathrm{cADPR}$ containing $5 \mu \mathrm{Ci}$ of $\left[{ }^{32} \mathrm{P}\right] \mathrm{cADPR}$, prepared as described previously $[16,22,23]$ for assessing cADPR hydrolase. Reaction products were analysed by high performance liquid chromatography $[16,22,23]$ using a flow scintillation analyser (FlowOne Beta-525TR, Packard, Meriden, Conn., USA). The protein concentration was measured by the method of Bradford [25] using bovine serum albumin as a standard.

Statistical analysis. The association of polymorphisms with Type II diabetes mellitus was analysed by $2 \times 2$ contingency tables and the significance of differences was tested by Fisher's exact test. Results are presented as mean \pm SEM.

\section{Results}

All eight exons of the CD38 gene [21] were amplified in 31 Type II diabetes mellitus patients and analysed by single-stranded conformation polymorphism. Two variant patterns were noted in exons 3 and 4 (Fig. 1). Sequence analysis showed that one of these variants was a silent mutation in the codon for $\mathrm{Ile}^{168}$ from ATA to ATC (Fig.2). The second change resulted in an amino acid substitution in which $\operatorname{Arg}^{140}$ (CGG) was replaced by Trp (TGG). We then tested 90 nondiabetic control subjects for the presence of these two variants. The frequency of the $\mathrm{Ile}^{168}$ (ATC) allele was $16 \%$ in both patients with Type II diabetes mellitus and control subjects. In contrast, heterozygous polymorphism of $\mathrm{Arg}^{140} / \mathrm{Trp}$ was observed in 4 of 31 Type II diabetes mellitus patients who had first-degree and/or second-degree relative(s) with Type II diabetes mellitus, but not in any of the control subjects, and the allele frequencies were significantly different

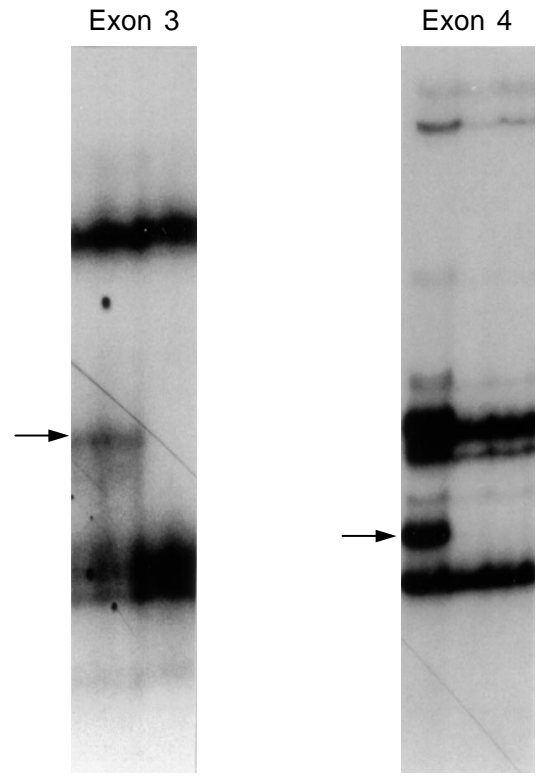

Fig. 1. Single-stranded conformation polymorphism analysis of exon 3 and exon 4. Exons 3 and 4 were amplified in vitro and the product was electrophoresed in a non-denaturing polyacrylamide gel $(0 \%$ glycerol $)$ at $4{ }^{\circ} \mathrm{C}$. The variant bands are indicated by arrows
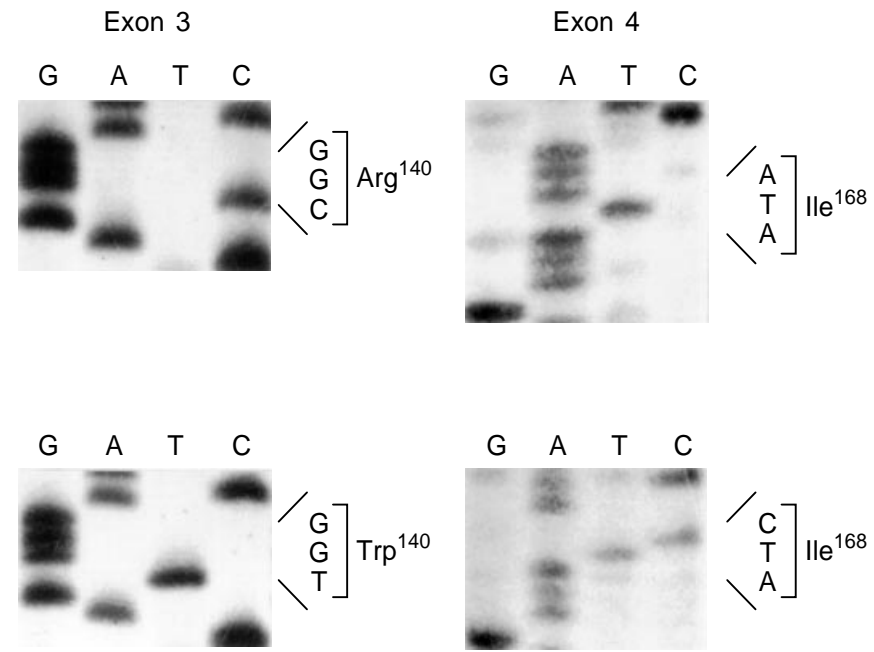

Fig. 2. Sequences of mutations in exons 3 and 4. Amplified products were subcloned into the phage vector M13 and sequenced. The sequences from the normal (upper) and variant alleles (lower) are shown

between the 31 Type II diabetes mellitus patients and the control subjects $(p=0.004)$ (Table 3$)$.

CD38 wild type and $\mathrm{Arg}^{140}$ Trp mutated expression vectors were constructed and introduced into COS-7 cells, and ADP-ribosyl cyclase and cADPR hydrolase activities were then measured. The mean ADPribosyl cyclase and cADPR hydrolase activities of the wild type CD38 in the three experiments were $2.49 \pm 0.44 \mathrm{nmol} \cdot \mathrm{min}^{-1} \cdot \mathrm{mg}$ protein $^{-1}$ and $10.99 \pm 1.94 \mathrm{nmol} \cdot \mathrm{min}^{-1} \cdot \mathrm{mg}$ protein ${ }^{-1}$, respectively. 
Table 3. Allele frequencies of the missense and silent mutations of the CD 38 gene in control subjects and in Japanese patients with Type II diabetes who had a family history of Type II diabetes

\begin{tabular}{|c|c|c|c|c|c|}
\hline & \multicolumn{2}{|c|}{$\begin{array}{l}\text { Control subjects } \\
(n=90)\end{array}$} & \multicolumn{2}{|c|}{$\begin{array}{l}\text { Patients with Type II } \\
\text { diabetes }(n=31)\end{array}$} & \multirow[t]{2}{*}{$\begin{array}{l}P \\
\text { value* }\end{array}$} \\
\hline & $n$ & Frequency & $n$ & Frequency & \\
\hline $\operatorname{Arg}^{140} \operatorname{Trp}$ & 0 & 0 & 4 & 0.065 & $p=0.004$ \\
\hline $\mathrm{Ile}^{168}$ & 27 & 0.15 & 10 & 0.16 & NS \\
\hline
\end{tabular}

* Fisher's exact test. The number in parenthesis is the number of subjects studied in each case

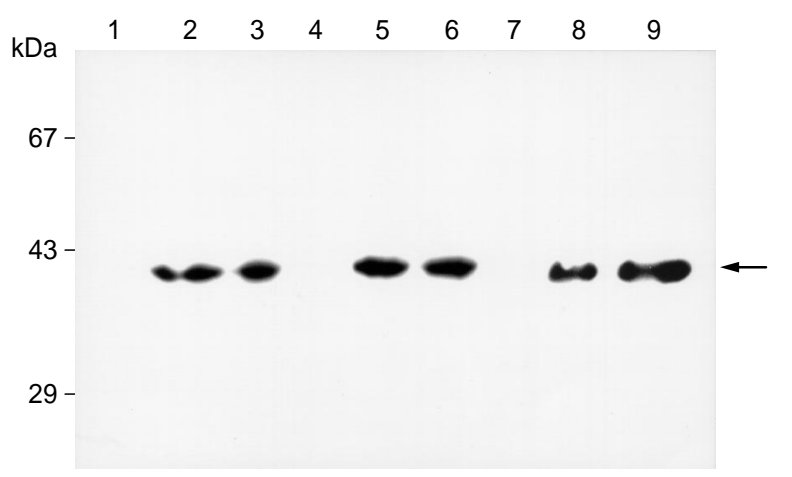

A

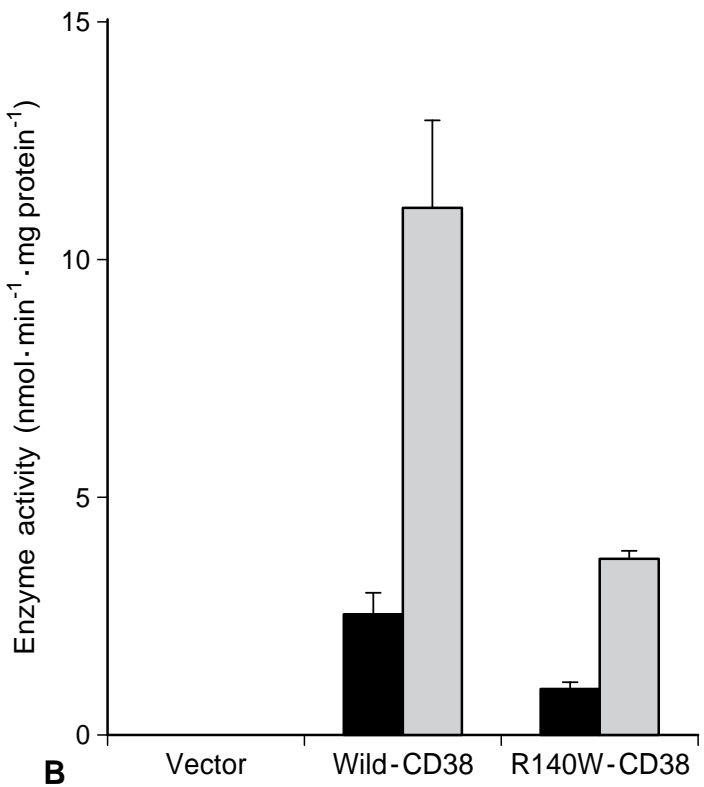

Fig. 3. ADP-ribosyl cyclase and cADPR hydrolase activities of the CD38 Arg ${ }^{140}$ Trp mutant. COS-7 cells were transfected with either the pSV2 expression vector alone, wild-type CD38 (WTCD38), or the Arg ${ }^{140}$ Trp CD38 mutant (R140W-CD38). A. CD38 expression in COS-7 cells by Western blot analysis. Lanes 1, 4 and 7; homogenates of COS-7 cells into which pSV2 vector had been introduced. Lane 2, 5 and 8; homogenates of COS-7 cells into which wild type CD38 expression vector had been introduced. Lane 3, 6 and 9; homogenates of COS-7 cells into which mutant CD38 expression vector had been introduced. B. ADP-ribosyl cyclase (solid bar) and cADPR hydrolase (hatched bar) activities were measured in COS7 homogenates. Results are the mean \pm SEM of three independent experiments
Arg ${ }^{140}$ Trp-CD38 showed significantly lower ADP-ribosyl cyclase $\left(0.889 \pm 0.201 \mathrm{nmol} \cdot \mathrm{min}^{-1} \cdot \mathrm{mg}\right.$ protein $^{-1}$ ) and cADPR hydrolase activities (3.677 \pm $0.187 \mathrm{nmol} \cdot \mathrm{min}^{-1} \cdot \mathrm{mg}$ protein ${ }^{-1}$ ) than non-mutated CD38 (Fig.3). COS-7 homogenates into which the control vector ( $\mathrm{pSV} 2$ vector) had been introduced exhibited no ADP-ribosyl cyclase, cADPR hydrolase, or $\mathrm{NAD}^{+}$-glycohydrolase activities.

\section{Discussion}

The appreciable reduction in both ADP-ribosyl cyclase and cADPR hydrolase activities caused by the $\mathrm{Arg}^{140} \operatorname{Trp}$ mutation in CD38 shows that this mutation could contribute to the impairment of insulin secretion in vivo in patients with Type II diabetes mellitus. cADPR is thought to have a second messenger role in insulin secretion through $\mathrm{Ca}^{2+}$ mobilisation [10-12]. As CD38 has both ADP-ribosyl cyclase and cADPR hydrolase activities, and ATP inhibits the cADPR hydrolase activity $[11,26]$, CD38 may regulate glucoseinduced insulin secretion in islets [11, 16-18]. Our expression study suggests that this mutation is involved in the development of Type II diabetes mellitus via the impairment of glucose-induced insulin secretion.

The exact biological effect of the Arg ${ }^{140}$ Trp mutation on the function of CD38 is not known. Arg ${ }^{140}$ is conserved between human CD38 and the homologous Aplysia ADP-ribosyl cyclases [17]. The charged $\mathrm{R}$ group of arginine has key roles in stabilisation of specific protein conformations via the formation of salt bonds. Mutation of $\mathrm{Arg}^{140}$ to a Trp residue containing an aromatic ring would affect the stabilisation of CD38, possibly resulting in a reduction in enzymatic activity. According to a recent report [27], the residue may be important for ligand binding, and thus, this mutation is predicted to affect CD38 activity.

The heterozygous carriers of the $\mathrm{Arg}^{140} \mathrm{Trp}$ mutation were found in the patients who had first-degree and/or second-degree relative(s) with Type II diabetes mellitus, and the allele frequencies were significantly different between the patients with family history of diabetes and the control subjects. Thus, this mutation is associated with Japanese Type II diabetes mellitus having a familial aggregation of this disease. Indeed, one patient with this mutation has the Val ${ }^{101}$ Ile and $\mathrm{Gly}^{519} \mathrm{Glu}$ mutations on the beta cell/liver glucose transporter (GLUT2) gene, and her mother, with impaired glucose tolerance, has this mutation on the CD38 gene and the $\mathrm{Val}^{101}$ Ile mutation on the GLUT2 gene [28]. In these patients, the decreased function of CD38 mutant may contribute to the impairment of the glucose-stimulated insulin secretion in association with the GLUT2 mutants. Segregation analysis of Type II diabetes mellitus has, for the most part, excluded the hypothesis that Type II diabetes mellitus is controlled by a single major gene 
[29]. The Arg ${ }^{140}$ Trp mutation on CD38 gene may contribute to the development of Type II diabetes mellitus in the presence of other genetic defects in beta cell function and insulin action.

Acknowledgements. We thank Drs. M. Taira, M. Kuramoto, J. Suzuki, N. Ishizuka, N. Seki, K. Sakurai, R. Fujii (Chiba University), and K. Sakuma (Nagazu Kashiwado Clinic) for support and Ms. Amano for technical assistance.

\section{References}

1. DeFronzo RA, Bonadonna RC, Ferrannini E (1992) Pathogenesis of NIDDM: a balanced overview. Diabetes Care 15: 318-368

2. Steiner DF, Tager HS, Chan SJ, Nanjo K, Sanke T, Rubinstein AH (1990) Lessons learned from molecular biology of insulin gene mutations. Diabetes Care 13: 600-609

3. Taylor SI, Cama A, Accili D (1992) Mutations in the insulin receptor gene. Endocrine Rev 13: 566-595

4. Makino H, Taira M, Shimada F (1992) Insulin receptor gene mutation: A molecular genetical and functional analysis. Cellular Signaling 4: 351-363

5. Froguel P, Zouali H, Vionnet N et al. (1993) Familial hyperglycemia due to mutation in glucokinase. $\mathrm{N}$ Eng $\mathrm{J}$ Med 328: 697-702

6. Hattersley AT, Turner RC, Permutt MA et al. (1992) Linkage of type 2 diabetes to the glucokinase gene. Lancet 339: $1307-1310$

7. Shimada F, Makino H, Hashimoto H et al. (1993) Type 2 (non-insulin-dependent) diabetes mellitus associated with a mutation of the glucokinase gene in a Japanese family. Diabetologia 36: 433-437

8. Ballinger SW, Shoffner JM, Hedaya EV et al. (1992) Maternally transmitted diabetes and deafness associated with a $10.4 \mathrm{~kb}$ mitochondrial DNA deletion. Nature Genet 1: $11-15$

9. van der Ouweland JMV, Lemkes HHPJ, Ruitenbeek W et al. (1992) Mutation in mitochondrial tRNA ${ }^{\text {Leu(UUR) }}$ gene in a large pedigree with maternally transmitted type II diabetes mellitus and deafness. Nature Genet 1: 368-371

10. Takasawa S, Nata K, Yonekura H, Okamoto H (1993) Cyclic ADP-ribose in insulin secretion from pancreatic $\beta$ cells. Science 259: 370-373

11. Okamoto H, Takasawa S, Nata K (1997) The CD38-cyclic ADP-ribose signalling system in insulin secretion: molecular basis and clinical implications. Diabetologia 40: 1485-1491

12. Takasawa S, Akiyama T, Nata K et al. (1998) Cyclic ADPribose and inositol 1, 4, 5-triphosphate as alternate second messengers for intracellular $\mathrm{Ca}^{2+}$ mobilization in normal and diabetic $\beta$-cells. J Biol Chem 273: 2497-2500

13. Islam MS, Larsson O, Berggren PO (1993) Cyclic ADP-ribose in $\beta$ cells. Science 262: $584-585$

14. Rutter GA, Theler JM, Li G, Wollheim CB (1994) $\mathrm{Ca}^{2+}$ stores in insulin-secreting cells: lack of effect of cADP ribose. Cell Calcium 16: 71-80
15. Webb D-L, Islam MS, Efanov AM et al. (1996) Insulin exocytosis and glucose-mediated increase in cytoplasmic free $\mathrm{Ca}^{2+}$ concentration in the pancreatic $\beta$-cell are independent of cyclic ADP-ribose. J Biol Chem 271: 19074-19079

16. Takasawa S, Tohgo A, Noguchi N et al. (1993) Synthesis and hydrolysis of cyclic ADP-ribose by human leukocyte antigen CD38 and inhibition of the hydrolysis by ATP. J Biol Chem 268: 26052-26054

17. Koguma T, Takasawa S, Tohgo A et al. (1994) Cloning and characterization of cDNA encoding rat ADP-ribosyl cyclase/cyclic ADP-ribose hydrolase (homologue to human CD38) from islets of Langerhans. Biochim Biophys Acta 1223: $160-162$

18. Kato I, Takasawa S, Akabane A et al. (1995) Regulatory role of CD38 (ADP-ribosyl cyclase/cyclic ADP-ribose hydrolase) in insulin secretion by glucose in pancreatic $\beta$ cells. J Biol Chem 270: 30,045-30,050

19. World Health Organization Study Group on Diabetes Mellitus (1985) Technical Report Series No 727, WHO, Geneva, pp 1-113

20. Sambrook F, Fritsch EF, Maniatis T (1989) Molecular cloning: a laboratory manual. 2nd edn. Cold Spring Harbor, New York

21. Nata K, Takamura T, Karasawa Tet al. (1997) Human gene encoding CD38 (ADP-ribosyl cyclase/cyclic ADP-ribose hydrolase): organization, nucleotide sequence and alternative splicing. Gene 186: 285-292

22. Tohgo A, Takasawa S, Noguchi N et al. (1994) Essential cysteine residues for cyclic ADP-ribose synthesis and hydrolysis by CD38. J Biol Chem 269: 28555-28557

23. Okamoto H, Takasawa S, Tohgo A, Nata K, Kato I, Noguchi N (1997) Synthesis and hydrolysis of cyclic ADP-ribose by human leukocyte antigen CD38: Inhibition of hydrolysis by ATP and the physiological significance. Method Enzymol 280: 306-318

24. Knapp W (1989) Antibody code list of the B cell workshop section. Tissue antigens 33: 123

25. Bradfold MM (1976) A rapid and sensitive method for the quantitation of microgram quantities of protein utilizing the principle of protein-dye binding. Anal Biochem 72: 248-254

26. Tohgo A, Munakata H, Takasawa S et al. (1997) Lysine 129 of CD38 (ADP-ribosyl cyclase/cyclic ADP-ribose hydrolase) participates in the binding of ATP to inhibit the cyclic ADP-ribose hydrolase. J Biol Chem 272: 3879-3882

27. Prasad GS, McRee DE, Stura EA, Levitt DG, Lee HC, Stout CD (1996) Crystal structural of Aplysia ADP ribosyl cyclase, a homologue of the bifunctional ectozyme CD 38. Nature Struct Biol 3: 957-964

28. Shimada F, Makino H, Iwaoka H et al. (1995) Identification of two novel amino acid polymorphisms in beta-cell/ liver (GLUT2) glucose transporter in Japanese subjects. Diabetologia 38: 211-215

29. Rotter JR, Vadheim CM, Rimoin DL (1990) Genetics of diabetes mellitus. In: Rifkin H, Porte D Jr (eds) Diabetes mellitus theory and practice. Elsevier, New York, pp 378-413 